\title{
Front Matter: Volume 7711
}

, "Front Matter: Volume 7711," Proc. SPIE 7711, Metamaterials V, 771101 (21 May 2010); doi: 10.1117/12.865890

SPIE. Event: SPIE Photonics Europe, 2010, Brussels, Belgium 


\title{
PROCEEDINGS OF SPIE
}

\section{Metamaterials $V$}

\author{
Nigel P. Johnson \\ Ekmel Özbay \\ Richard W. Ziolkowski \\ Nikolay I. Zheludev \\ Editors
}

12-16 April 2010

Brussels, Belgium

Sponsored by

SPIE

Cosponsored by

B-PHOT—Brussels Photonics Team (Belgium) • Brussels-Capital Region (Belgium) • FWO_Fonds Wetenschappelijk Onderzoek (Belgium) • ICO_International Commission for Optics • Ville de Bruxelles (Belgium)

Cooperating Organisations

CBO-BCO (Belgium) • EOS-European Optical Society (Germany) • IET-The Institution of Engineering and Technology (United Kingdom) $\bullet$ IOP_Institute of Physics (United Kingdom) Photonics4Life (Germany) • Photonics@be (Belgium) • Photonics 21 (Germany) • PromOptica (Belgium)

Published by

SPIE

Volume 7711

Proceedings of SPIE, 0277-786X, v. 7711 
The papers included in this volume were part of the technical conference cited on the cover and title page. Papers were selected and subject to review by the editors and conference program committee. Some conference presentations may not be available for publication. The papers published in these proceedings reflect the work and thoughts of the authors and are published herein as submitted. The publisher is not responsible for the validity of the information or for any outcomes resulting from reliance thereon.

Please use the following format to cite material from this book:

Author(s), "Title of Paper," in Metamaterials V, edited by Nigel P. Johnson, Ekmel Özbay, Richard W. Ziolkowski, Nikolay I. Zheludev, Proceedings of SPIE Vol. 7711 (SPIE, Bellingham, WA, 2010) Article CID Number.

ISSN 0277-786X

ISBN 9780819481849

Published by

SPIE

P.O. Box 10, Bellingham, Washington 98227-0010 USA

Telephone +1 3606763290 (Pacific Time) · Fax +1 3606471445

SPIE.org

Copyright (C) 2010, Society of Photo-Optical Instrumentation Engineers

Copying of material in this book for internal or personal use, or for the internal or personal use of specific clients, beyond the fair use provisions granted by the U.S. Copyright Law is authorized by SPIE subject to payment of copying fees. The Transactional Reporting Service base fee for this volume is $\$ 18.00$ per article (or portion thereof), which should be paid directly to the Copyright Clearance Center (CCC), 222 Rosewood Drive, Danvers, MA 01923. Payment may also be made electronically through CCC Online at copyright.com. Other copying for republication, resale, advertising or promotion, or any form of systematic or multiple reproduction of any material in this book is prohibited except with permission in writing from the publisher. The CCC fee code is 0277-786X/10/\$18.00.

Printed in the United States of America.

Publication of record for individual papers is online in the SPIE Digital Library.

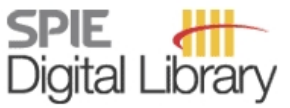

SPIEDigitalLibrary.org

Paper Numbering: Proceedings of SPIE follow an e-First publication model, with papers published first online and then in print and on CD-ROM. Papers are published as they are submitted and meet publication criteria. A unique, consistent, permanent citation identifier (CID) number is assigned to each article at the time of the first publication. Utilization of CIDs allows articles to be fully citable as soon they are published online, and connects the same identifier to all online, print, and electronic versions of the publication. SPIE uses a six-digit CID article numbering system in which:

- The first four digits correspond to the SPIE volume number.

- The last two digits indicate publication order within the volume using a Base 36 numbering system employing both numerals and letters. These two-number sets start with 00, 01, 02, 03, 04, $05,06,07,08,09,0 A, 0 B \ldots 0 Z$, followed by 10-1Z, 20-2Z, etc.

The CID number appears on each page of the manuscript. The complete citation is used on the first page, and an abbreviated version on subsequent pages. Numbers in the index correspond to the last two digits of the six-digit CID number. 


\title{
Contents
}

\author{
vii Conference Committee \\ ix Introduction
}

\section{SESSION 1 METAMATERIALS PAST AND PRESENT}

771104 Bright spatial solitons, nonlinear guided waves, and complex metamaterial structures (Invited Paper) [7711-03]

A. D. Boardman, P. Egan, R. C. Mitchell-Thomas, Univ. of Salford (United Kingdom);

Y. G. Rapoport, National Taras Shevchenko Univ. of Kyiv (Ukraine); L. Velasco, Univ. of Salford (United Kingdom)

\section{SESSION 2 PLASMONIC METAMATERIALS}

771108 Enlarged negative effective index bandwidth from fishnet metamaterials [771 1-07] R. Ortuño, C. García-Meca, F. J. Rodríguez-Fortuño, J. Martí, A. Martínez, Univ. Politécnica de Valencia (Spain)

771109 Optical chirality in plasmonic arrays of subwavelength Z-shaped apertures [7711-08] M. R. Shcherbakov, P. P. Vabishchevich, M. I. Dobynde, T. V. Dolgova, Lomonosov Moscow State Univ. (Russian Federation); E. D. Mishina, A. S. Sigov, Moscow Institute of Radioengeneering, Electronics and Automation (Russian Federation); A. A. Fedyanin, Lomonosov Moscow State Univ. (Russian Federation)

\section{SESSION $3 \quad$ LENSING}

$77110 \mathrm{Influence}$ of fabrication accuracies of metal-dielectric layered flat lenses on their imaging properties [7711-14]

T. Stefaniuk, R. Kotyński, Univ. of Warsaw (Poland); G. Nowak, Institute of High Pressure Physics (Poland); T. Szoplik, Univ. of Warsaw (Poland)

$77110 \mathrm{O} \quad$ Optimisation of a plasmonic nanolens: increase of transmission and focal length [7711-16] P. Wróbel, T. J. Antosiewicz, T. Szoplik, Univ. of Warsaw (Poland)

\section{SESSION 4 TERAHERTZ TECHNOLOGY}

$77110 \mathrm{~J}$ Design of millimeter wave heterodyne receivers based on metamaterial technology (Invited Paper) [7711-17]

I. Ederra, I. Khromova, R. Gonzalo, Univ. Pública de Navarra (Spain); B. Alderman, Rutherford Appleton Lab. (United Kingdom); A. Murk, Univ. of Bern (Switzerland); N. Delhote, D. Baillargeat, Univ. of Limoges (France); P. de Maagt, European Space Agency (Netherlands) 
$7711 \mathrm{OL}$ A sensitivity analysis of frequency selective surface based metamaterial at THz frequency [7711-19]

S. Islam, J. Stiens, R. Vounckx, Vrije Univ. Brussel (Belgium)

7711 OM Fractal THz metamaterials: design, fabrication, and characterisation [771 1-20]

R. Malureanu, P. U. Jepsen, Technical Univ. of Denmark (Denmark); S. Xiao, L. Zhou, Fudan Univ. (China); D. G. Cooke, A. Andryieuski, A. V. Lavrinenko, Technical Univ. of Denmark (Denmark)

\section{SESSION 5 3D METAMATERIALS}

$77110 \mathrm{Subwavelength}$ optical cavities with high quality factor [7711-28]

V. Ginis, Vrije Univ. Brussel (Belgium); P. Tassin, Vrije Univ. Brussel (Belgium) and lowa State Univ. (United States); C. M. Soukoulis, Iowa State Univ. (United States) and Univ. of Crete (Greece); I. Veretennicoff, Vrije Univ. Brussel (Belgium)

\section{SESSION $6 \quad$ ACTIVE METAMATERIALS}

7711 OW Effective parameters of split-ring arrays, numerically determined by frequency-dependent homogenization (Invited Paper) [7711-30]

M. H. Belyamoun, A. Bossavit, S. Zouhdi, LGEP-Supelec (France)

\section{SESSION 7 OPTICAL METAMATERIALS AND CLOAKING}

771111 Metamaterial-based cloaking with sparse distribution of spiral resonators (Invited Paper) [7711-35]

K. Guven, Koç Univ. (Turkey); E. Saenz, R. Gonzalo, Public Univ. of Navarra (Spain); E. Ozbay, Bilkent Univ. (Turkey); S. Tretyakov, Aalto Univ. School of Science and Technology (Finland)

771116 Split ring resonators: the effect of titanium adhesion layers on the optical response [7711-40] B. Lahiri, R. Dylewicz, Univ. of Glasgow (United Kingdom); S. G. McMeekin, Glasgow Caledonian Univ. (United Kingdom); A. Z. Khokhar, R. M. De La Rue, N. P. Johnson, Univ. of Glasgow (United Kingdom)

\section{SESSION 8 NOVEL METAMATERIALS STRUCTURES I}

771119 Geometry-function relationship in meta-foils (Invited Paper) [771 1-43]

H. O. Moser, L. K. Jian, National Univ. of Singapore (Singapore); H. S. Chen, Zhejiang Univ. (China) and Massachusetts Institute of Technology (United States); S. M. P. Kalaiselvi, S. Virasawmy, National Univ. of Singapore (Singapore); X. X. Cheng, Zhejiang Univ. (China); A. Banas, K. Banas, S. P. Heussler, National Univ. of Singapore (Singapore); M. Bahou, National Chiao Tung Univ. (Singapore); B.-I. Wu, Zhejiang Univ. (China) and Massachusetts Institute of Technology (United States); W. Hua, National Univ. of Singapore (Singapore); Z. Yi, National Univ. of Singapore (Singapore) and Institute of Chemical and Engineering Sciences (Singapore) 
7711 1A Colloidal chemistry routes for fabrication of nanoparticle-based metamaterials (Invited Paper) [7711-44]

M. Corricelli, CNR, IPCF, Univ. di Bari (Italy) and Univ. di Bari (Italy); M. Striccoli, R. Comparelli,

M. L. Curri, CNR, IPCF, Univ. di Bari (Italy)

\section{SESSION 9 NOVEL METAMATERIALS STRUCTURES II}

7711 1C Trapped rainbow storage of light in metamaterials (Invited Paper) [771 1-46]

K. L. Tsakmakidis, E. I. Kirby, J. Hamm, O. Hess, Univ. of Surrey (United Kingdom)

7711 1F Coupling between surface plasmons and Fabry-Pérot modes in metallic double meander structures [7711-49]

P. Schau, K. Frenner, L. Fu, H. Schweizer, W. Osten, Univ. Stuttgart (Germany)

$77111 \mathrm{H} \quad$ A scalable multi-allowed band bandpass filter demonstrating ultra-wide-bandwidth, excellent efficiency, and sharp band-edge transition [7711-51]

T.-Y. Huang, T.-J. Yen, National Tsing Hua Univ. (Taiwan)

SESSION 10 TUNING AND SWITCHING OF METAMATERIALS I

$77111 \mathrm{~K} \quad$ Capacitance tuning of nanoscale split-ring resonators (Invited Paper) [771 1-54]

C. Jeppesen, S. Xiao, N. A. Mortensen, A. Kristensen, Technical Univ. of Denmark (Denmark)

$77111 \mathrm{M} \quad$ Modulation of refractive index caused by amplitude variation and heterogeneity of anchoring forces in nanosphere-doped liquid crystal metamaterial: Monte Carlo analysis [7711-56]

G. Pawlik, M. Jarema, W. Walasik, A. C. Mitus, Wroclaw Univ. of Technology (Poland);

I. C. Khoo, The Pennsylvania State Univ. (United States)

SESSION 11 TUNING AND SWITCHING OF METAMATERIALS II

$77111 \mathrm{~N} \quad$ Tuning methods for metamaterials (Invited Paper) [7711-58]

M. Lapine, Univ. of Seville (Spain); D. Powell, The Australian National Univ. (Australia);

M. Gorkunov, A.V. Shubnikov Institute of Crystallography (Russian Federation); I. Shadrivov,

Yu. Kivshar, The Australian National Univ. (Australia)

$77111 Q \quad$ Metal-dielectric composites with tunable optical properties [7711-61]

R. B. Nielsen, A. Kristensen, J. M. Hvam, Technical Univ. of Denmark (Denmark);

A. Boltasseva, Technical Univ. of Denmark (Denmark), Purdue Univ. (United States), and

Friedrich-Alexander-Univ. Erlangen-Nürnberg (Germany)

SESSION 12 NANO-METAMATERIALS

7711 is Asymmetric second harmonic generation in chiral optical metamaterials [7711-64]

V. K. Valev, A. V. Silhanek, W. Gillijns, Katholieke Univ. Leuven (Belgium); O. A. Aktsipetrov, Lomonosov Moscow State Univ. (Russian Federation); V. V. Moshchalkov, T. Verbiest, Katholieke Univ. Leuven (Belgium) 
7711 1T Experimental determination of principal permittivities and hyperbolic equi-frequency surfaces in silver nanowire arrays [7711-65]

J. Schilling, Queen's Univ. Belfast (United Kingdom) and Martin-Luther-Univ. Halle-Wittenberg (Germany); J. Kanungo, Queen's Univ. Belfast (United Kingdom)

7711 1V Near-field spectroscopy of nanostructures (Invited Paper) [7711-67]

Z. Shen, Y. Ma, H. Hu, J. Kasim, Nanyang Technological Univ. (Singapore)

7711 IW Localizing and focusing second-harmonic emission with nonlinear metamaterials [771 1-68] C. Ciracì, GES, CNRS, Univ. Montpellier 2 (France); E. Centeno, Univ. Blaise Pascal (France)

\section{POSTER SESSION}

$77111 \mathrm{X}$ An experimental study of the effects of various parameters on the resonant and efficiency of circular split-ring resonators (Best Student Paper Award) [7711-69]

A. Elhawil, J. Stiens, C. De Tandt, W. Ranson, R. Vounckx, Vrije Univ. Brussel (Belgium)

7711 1Y Chiral waves in a metamaterial medium [7711-70]

C. Bao, La Rioja Univ. (Spain); J. M. Castresana, Basque Country Univ. (Spain)

$771121 \quad$ Light compression without reflections [7711-73]

C. García-Meca, M. Tung, J. V. Galán, R. Ortuño, F. J. Rodríguez-Fortuño, J. Martí, A. Martínez, Univ. Politécnica de Valencia (Spain)

771122 Imaging in the visible wavelength range through anisotropic layered flat lens operating in the canalization regime [7711-74]

A. Pastuszczak, R. Kotyński, Univ. of Warsaw (Poland)

Author Index 


\title{
Conference Committee
}

\author{
Symposium Chairs
}

Francis Berghmans, Vrije Universiteit Brussel (Belgium)

Ronan Burgess, European Commission (Belgium)

Jürgen Popp, Institut für Photonische Technologien e.V. (Germany)

Peter Hartmann, SCHOTT AG (Germany)

Hugo Thienpont, Vrije Universiteit Brussel (Belgium)

\section{Conference Chairs}

Nigel P. Johnson, University of Glasgow (United Kingdom)

Ekmel Özbay, Bilkent University (Turkey)

Richard W. Ziolkowski, CREATE Homeland Security Center (United

States)

Nikolay I. Zheludev, University of Southampton (United Kingdom)

Program Committee

Allan D. Boardman, University of Salford (United Kingdom)

Sergey I. Bozhevolnyi, University of Southern Denmark (Denmark)

Filippo Capolino, Università degli Studi di Siena (Italy)

Enzo M. Di Fabrizio, Università degli studi Magna Graecia di Catanzaro (Italy)

Ramon Gonzalo, Universidad Pública de Navarra (Spain)

Maria Kafesaki, Foundation for Research and Technology-Hellas (Greece)

Vladimir Kuzmiak, Institute of Photonics and Electronics of the Academy of Sciences CR, v.v.i. (Czech Republic)

Ulf Leonhardt, University of St. Andrews (United Kingdom)

Herbert O. Moser, National University of Singapore (Singapore)

Willie J. Padilla, Boston College (United States)

Costas M. Soukoulis, lowa State University (United States)

Srinivas Sridhar, Northeastern University (United States)

Tomasz Szoplik, University of Warsaw (Poland)

Sergei G. Tikhodeev, A. M. Prokhorov General Physics Institute (Russian Federation)

Sergei Tretyakov, Aalto University School of Science and Technology (Finland)

Markus Walther, Albert-Ludwigs-Universität Freiburg (Germany)

Martin Wegener, Karlsruhe Institute of Technology (Germany)

Said Zouhdi, Laboratoire de Génie Electrique de Paris, Supélec (France) 
Session Chairs

1 Metamaterials Past and Present

Nader Engheta, University of Pennsylvania (United States)

2 Plasmonic Metamaterials

Allan D. Boardman, University of Salford (United Kingdom)

$3 \quad$ Lensing

Richard D. Averitt, Boston University (United States)

$4 \quad$ Terahertz Technology

Mikhail Lapine, Universidad de Sevilla (Spain)

5 3D Metamaterials

Maria Kafesaki, Foundation for Research and Technology-Hellas (Greece)

6 Active Metamaterials

Sergei Tretyakov, Aalto University School of Science and Technology (Finland)

$7 \quad$ Optical Metamaterials and Cloaking

Willie J. Padilla, Boston College (United States)

8 Novel Metamaterials Structure I

Ortwin Hess, University of Surrey (United Kingdom)

9 Novel Metamaterials Structures II

Nikolay A. Gippius, Université Blaise Pascal (France)

10 Tuning and Switching of Metamaterials I

Jeong-Weon Wu, Ewha Womans University (Korea, Republic of)

11 Tuning and Switching of Metamaterials II

Maria Kafesaki, Foundation for Research and Technology-Hellas

(Greece)

12 Nano-Metamaterials

Nigel P. Johnson, University of Glasgow (United Kingdom) 


\title{
Introduction
}

The controversy once associated with metamaterials, artificial subwavelength structures which involve the interaction of electromagnetic radiation, has now subsided. As the subject evolves, optical and nano-metamaterials have become more prominent. This was reflected in the large number of papers presented in the sessions entitled Lensing, Optical Metamaterials and Cloaking, and NanoMetamaterials. Convergence with some aspects of plasmonics is also evident. Three-dimensional fabrication methods and novel structures were well represented covering three sessions. Tuning and switching of metamaterials continues to move the topic closer to devices. Once again in this meeting, we placed emphasis on optical (and infrared) metamaterials, but also include the important terahertz region. The opening session put many of these aspects in context.

Brussels was the new host for this conference with the venue ideally situated in the heart of the city. Some contributors may have had an unexpected extended stay and found unusual modes of transport home, but we trust this is not the only reason for a memorable conference. This conference is the fifth in the series of metamaterials-the first occurring at the SPIE meeting in Warsaw 2005, followed by Prague in 2007, Strasbourg in 2008, and returning to Prague in 2009. It is hoped that the tradition of an eastern and western European venue will continue.

The chairs of the meeting would like to thank all contributors to the conference, the SPIE team, and the programme committee.

\author{
Nigel P. Johnson \\ Ekmel Özbay \\ Richard W. Ziolkowski \\ Nikolay I. Zheludev
}


Downloaded From: https://www.spiedigitallibrary.org/conference-proceedings-of-spie on 26 Apr 2023

Terms of Use: https://www.spiedigitallibrary.org/terms-of-use 